\title{
High Specific Li-ion cells based on high voltage materials
}

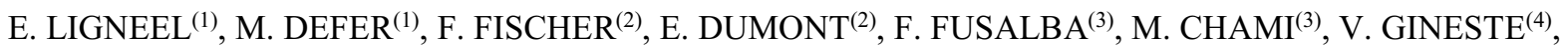 M. NESTORIDI ${ }^{(5)}$}

(1)SAFT Space and Defense Division, Poitiers, France,Email: mathieu.defer@saftbatteries.com, eric.ligneel@saftbatteries.com

(2)SAFT Research Department,Bordeaux, France,Email:florent.fischer@saftbatteries.com, erwan.dumont@saftbatteries.com

(3)CEA-Liten, Grenoble,France,Email:florence.fusalba@cea.fr, marianne.chami@cea.fr (4) Airbus Defence \& Space, Toulouse, France, Email: valery.gineste@airbus.com

(5) ESA/ESTEC, Keplerlaan 1, Postbox 299, 2200 AG Noordwijk - The Netherland, Email: Maria.Nestoridi@esa.int

\begin{abstract}
This paper presents the results obtain in the frame of the ESA TRP: High specific Li-ion cells based on high voltage materials.

As there is a need of high energy cells for Space application, a low TRL study was performed by Saft, CEA and ADS in order to developed high energy cells prototypes with a space proven cell mechanical design. The program was divided into 3 main parts.

1) Bibliographic study on the most promising active materials, $2^{\text {nd }}$ a laboratory

2) Laboratory scale study of the selected active materials

3) Realization and electrochemical evaluation of format D prototype cells
\end{abstract}

\section{INTRODUCTION}

ESA initiates this TRP activity in order that all European space missions would benefit by having more lightweight energy storage. By increasing the energy density of the lithium ion cells the weight of the spacecraft battery, and consequently the satellite weight will be reduced. In space applications, in Europe, lithium ion technology has been established as the state-of-the-art battery technology, since the launch of Proba 1 satellite in 2001. Lithium-ion cells provided a great improvement over their preceded technologies by reducing the mass and volume of the batteries and subsequently the cost of satellite launch, since that is directly related to the weight of the satellite. Further development towards higher energy density and therefore lighter lithium-ion cells will also enable the increase of functional payload weight and mission capabilities for space applications.

\section{OBJECTIVES}

The objective of this activity is to develop, manufacture and evaluate Lithium-ion prototype cells with high specific energy $(\geq 250 \mathbf{~ W h} / \mathbf{k g})$. This work will be done by SAFT in collaboration with CEA and ADS. It consists in choosing potential active materials, to test them separately in half coin cell versus $\mathrm{Li}^{\circ}$, and then to integrate them in full prototype cells. The prototype cell design is a space proven Format D industrial design used by SAFT. Prototype cells must present cyclability with a fading of less than $20 \%$ after 300 cycles in Geostationary Earth Orbit (GEO) and Low Earth Orbit (LEO) conditions between $-10^{\circ} \mathrm{C}$ and $+50^{\circ} \mathrm{C}$.

\section{ACHIEVEMENTS}

3.1 Part 1: Bibliographic study and Active material selection

\subsubsection{Positive active material}

As presented on Figure 1, hight mass capacity and high potential can be reach by using NCA $\left(\mathrm{Li}\left(\mathrm{Ni}_{\mathrm{x}} \mathrm{Co}_{\mathrm{y}} \mathrm{Al}_{\mathrm{z}}\right) \mathrm{O}_{2}\right)$ and HE-NMC ( $\mathrm{Li}\left(\mathrm{Li}_{\mathrm{a}} \mathrm{Ni}_{1-\mathrm{x}-\mathrm{y}-}\right.$ $\left.{ }_{\mathrm{a}} \mathrm{Mn}_{\mathrm{x}} \mathrm{Co}_{\mathrm{y}}\right) \mathrm{O}_{2}$ ) materials.

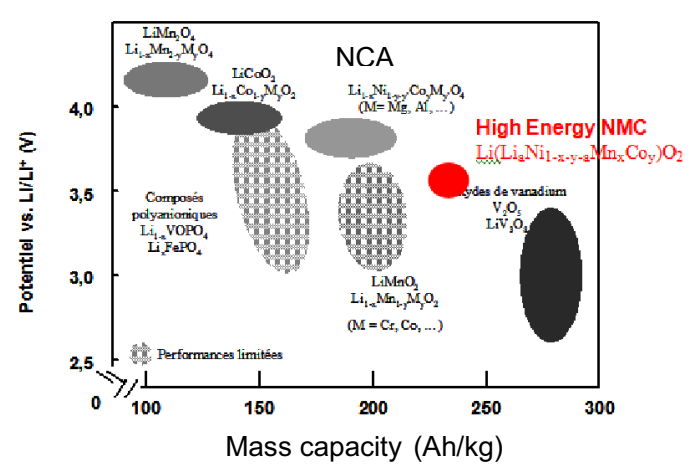

Figure 1: Comparison of several types of cathode materials depending on their specific capacity and their potential of insertion / deinsertion of lithium 
It has to be noted that NCA can be competitive versus HE-NMC if it is charged over its standard potential $\left(4.2 \mathrm{~V}\right.$ vs. $\left.\mathrm{Li}^{\circ}\right)$. This can accelerate its degradation during cycling if the grade is not coated.

For the next step of the study, HENMC and NCA materials will be tested in half coin cell.

\subsubsection{Negative active material}

On negative side, the purpose is to use an active material which has a low potential and a specific capacity close to $\mathrm{Li}^{\circ}$.

The target can be reached by using Si. However the use of pure $\mathrm{Si}$ is not recommended due it important volume change when lithiated (up to $300 \%$ ). This behavior doesn't permit to obtain a negative electrode with a stable SEI and conductive network during cycling.

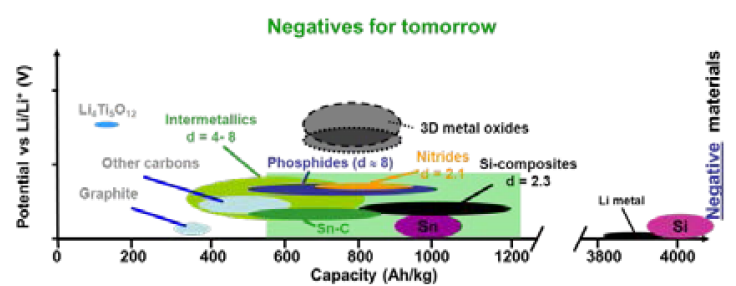

Figure 2: Potential use vs. Specific capacity of Negative active materials

A compromise is to use a mix of Si with Graphite or other non-metal compound.

For the next step, SAFT test Silicon carbon alloys and a Silicon non-metal compound alloy.

CEA adopt the same strategy by testing a Silicon carbon alloy.

\subsection{Half coin cells cyclings}

\subsubsection{Positive electrode}

NCA1 is non coated active material whereas NCA2 is a coated active material with the same stoichiometry. Despite a higher charge voltage and a coating, NCA active materials present a higher fading and specific capacity than grades of HENMC materials (HENMC 1 \& 2a) (Figure 3).

3 grades of HENMC were tested. Bad performances are obtained on grade named HENMC2b. The others present a good stability.

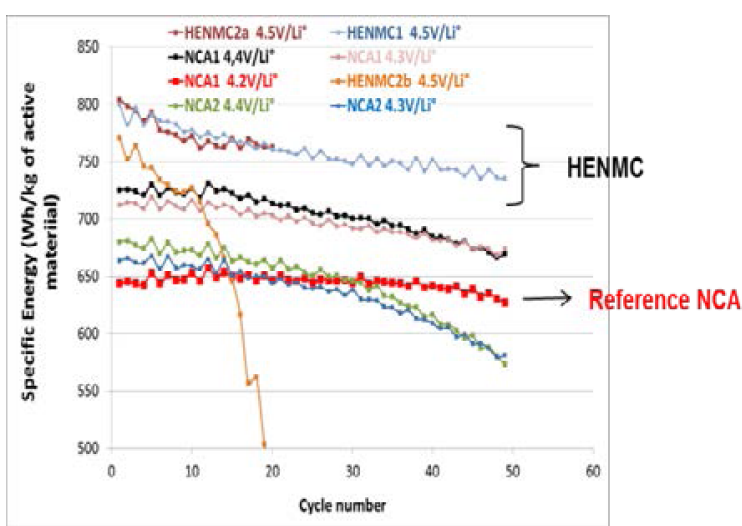

Figure 3: Comparisons of HENMC \& NCA, Specific Energy during Cycling at $\mathrm{C} / 5$

SAFT proposed to use HENMC $\mathbf{2 a}$ in prototype cells.

\subsubsection{Negative electrode}

\subsubsection{SAFT electrode}

A comparison between a $\mathrm{Si}$ carbon alloys mixed with additional graphite ( $\mathrm{SiC} 2 / \mathrm{C})$ and a non-metal Si compound alloy ( $\mathrm{SiX}$ ) was done (Figure 4). After 20 cycles, both materials present the same fading.

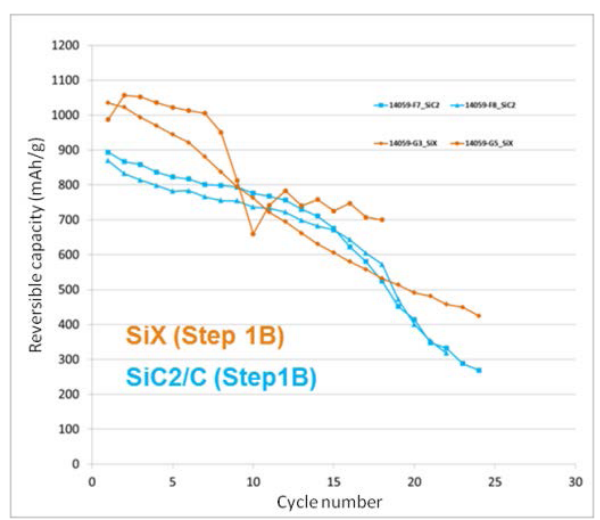

Figure 4: SAFT Negative materials, Cycling tests at C/5

This comparison was realized with a standard electrolyte. Material $\mathrm{SiC} 2 / \mathrm{C}$ was tested (Figure 5) with an optimized electrolyte rich in $\mathrm{VC}$ and FEC.

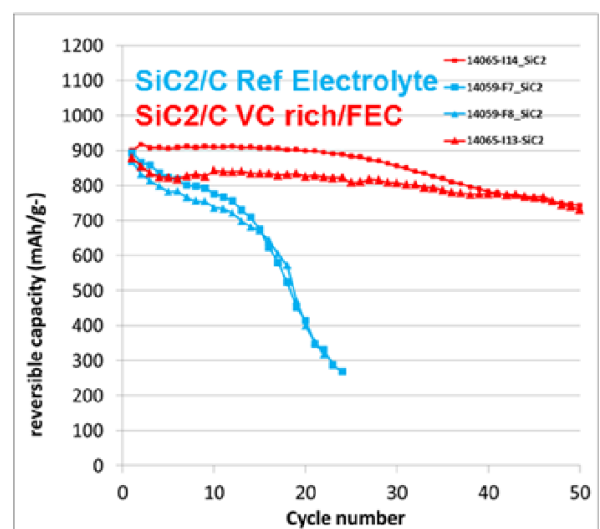

Figure 5: $\mathrm{SiC} 2$ cycling at $\mathrm{C} / 5$ with $\&$ without optimized electrolyte

The cycling results show the strong impact of electrolyte formulation on the cycling performances 
of a $\mathrm{Si}$ based electrode. It plays on the nature (chemical and mechanical) of SEI negative electrode which is able to manage active material volume change during cycling.

$\mathrm{SiC2} / \mathrm{C}$ was implemented in prototype cells.

\subsubsection{CEA electrode}

CEA proposes a Si carbon alloy electrode.

In order to limit its volume change during cycling, the electrode has to be cycled with a limited charged capacity. A good stability over 100 cycles can be obtained by cycling it with charge capacity of $750 \mathrm{mAh} / \mathrm{g}$ (Formulation D).

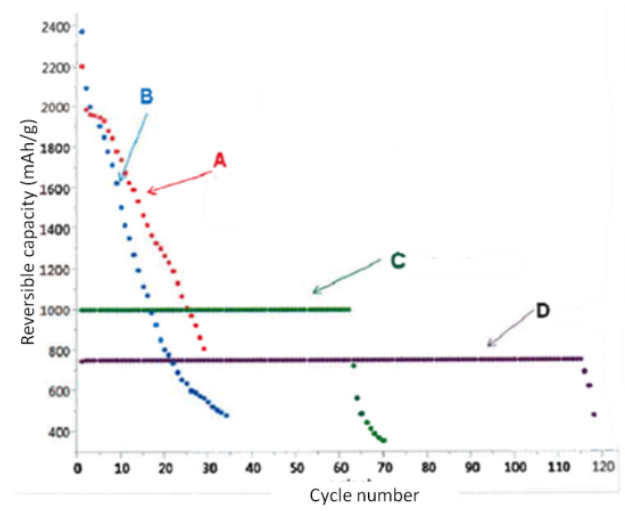

Figure 6: Negatives electrode from CEA cycling results (cycling at $\mathrm{C} / 5$ )

\subsection{Format D Prototype cells}

\subsubsection{Cell design characteristics}

Format D mechanical design is usually use for space cell VES16.

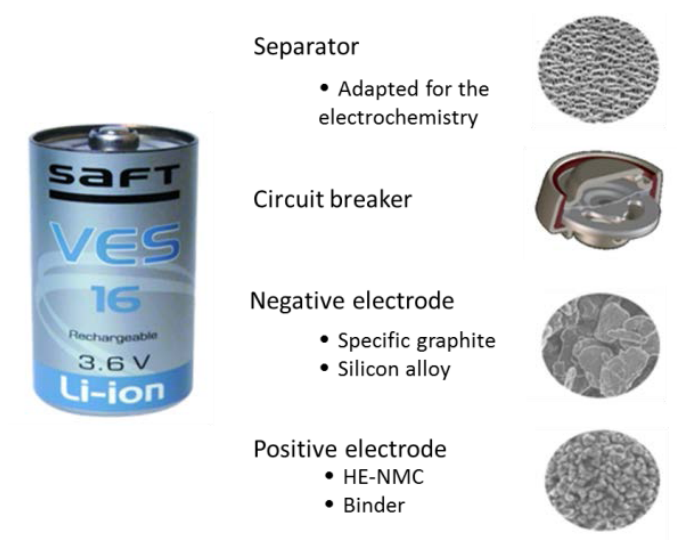

Figure 7: General overview of the cell

The main risks are identified and mitigated by specific countermeasure.

The gas generation during formation of the used electrochemistry is not well known. In order to not open the circuit breaker during cycling, the internal pressure was released after formation.
Despite silicon anode composition adjustments, there is still a possibility of high jelly roll swelling leading to separator puncture and tearing. This was mitigated by using a specific separator and manufacturing low jelly roll diameters.

2 series were manufactured.

- Serie 1: Cells manufactured with SAFT HENMC2a based positive electrode design and SAFT $\mathrm{SiC} 2 / \mathrm{C}$ based negative electrode design.

- Serie 2: Cells manufactured SAFT HE-NMC2a based positive electrode design and CEA Si based negative electrode design (Formulation D).

In order to favor cell cyclability, specific energy lower than $220 \mathrm{Wh} / \mathrm{kg}$ at D/10 are proposed (Table 1).

\begin{tabular}{|l|c|c|}
\hline & SAFT (-) electrode & CEA (-) electrode \\
\hline NominalCapacity & $7.25 \mathrm{Ah}$ & $6.87 \mathrm{Ah}$ \\
\hline Nominal Energy & $24 \mathrm{Wh}$ & $22.3 \mathrm{Wh}$ \\
\hline Specific Energy & $220 \mathrm{Wh} / \mathrm{kg}$ & $200 \mathrm{Wh} / \mathrm{kg}$ \\
\hline
\end{tabular}

At $\mathrm{D} / 2$, the main unknown parameter is the electrode behavior at high current rate in prototype $\mathrm{D}$ cell configuration. The estimation is based on SAFT heritage (Table 2).

\begin{tabular}{|l|c|c|}
\hline & SAFT (-) electrode & CEA (-) electrode \\
\hline NominalCapacity & $6.2 \mathrm{Ah}$ & $6.65 \mathrm{Ah}$ \\
\hline Nominal Energy & $20.8 \mathrm{Wh}$ & $21.6 \mathrm{Wh}$ \\
\hline Specific Energy & $190 \mathrm{Wh} / \mathrm{kg}$ & $194 \mathrm{Wh} / \mathrm{kg}$ \\
\hline
\end{tabular}

\subsubsection{Characterisation results}

\subsubsection{Characterization at $D / 10$ and $D / 2$}

Initially, the voltage range was $[2 \mathrm{~V}-4.4 \mathrm{~V}]$. But due to a high polarization of the electrodes, the obtained average specific energies are lower than design calculation (Figure 9) in this voltage range.

\begin{tabular}{|c|c|c|c|c|}
\hline & \multicolumn{3}{|c|}{ Discharge (D/10) } \\
\hline & & Ah & Wh & Wh/kg \\
\hline Serie 1 (Saft) & Average & 6,43 & 21,0 & 190 \\
\hline Serie 2 (Saft/CEA) & Average & 5,92 & 19,0 & 171 \\
\hline
\end{tabular}

\begin{tabular}{|c|c|c|c|c|}
\cline { 3 - 5 } \multicolumn{2}{c|}{} & \multicolumn{3}{c|}{ Discharge (D/2) } \\
\cline { 3 - 5 } \multicolumn{2}{c|}{} & Ah & Wh & Wh/kg \\
\hline Serie 1 (Saft) & Average & 6,12 & 19,1 & $\mathbf{1 7 3}$ \\
\hline Serie 2 (Saft/CEA) & Average & 5,58 & 17,3 & $\mathbf{1 5 5}$ \\
\hline
\end{tabular}

Table 4: Serie 1 \& Serie 2 cell characterization at $\mathrm{D} / 2$ for $\mathrm{EOCV}$ $=4.4 \mathrm{~V}$

For Serie 1, another characterization was performed at $\mathrm{D} / 10 \& \mathrm{D} / 2$ with a higher cell end of charge voltage $(\mathrm{EOCV})$ defined at $4.5 \mathrm{~V}$. Not enough cells 
were available for this kind of characterization on Serie 2.

\begin{tabular}{|c|c|c|c|c|}
\cline { 3 - 5 } \multicolumn{2}{c|}{} & \multicolumn{3}{c|}{ Discharge (D/10) } \\
\cline { 3 - 5 } \multicolumn{2}{c|}{} & Ah & Wh & Wh/kg \\
\hline $\begin{array}{c}\text { Serie 1 } \\
\text { EOCV = 4.4 V }\end{array}$ & Average & 6,43 & 21,0 & 190 \\
\hline $\begin{array}{c}\text { Serie 1 } \\
\text { EOCV = 4.5 V }\end{array}$ & Average & 6,56 & 21,5 & 195 \\
\hline
\end{tabular}

Table 5: Serie 1 cell characterization at $\mathrm{D} / 10$ for $\mathrm{EOCV}=4.4 \mathrm{~V}$ $\& 4.5 \mathrm{~V}$

\begin{tabular}{|c|c|c|c|c|}
\cline { 3 - 5 } \multicolumn{2}{c|}{} & \multicolumn{3}{c|}{ Discharge (D/2) } \\
\cline { 3 - 5 } \multicolumn{2}{c|}{} & Ah & Wh & Wh/kg \\
\hline $\begin{array}{c}\text { Serie 1 } \\
\text { EODV = 4.5 V }\end{array}$ & Average & 6,12 & 19,1 & $\mathbf{1 7 3}$ \\
\hline $\begin{array}{c}\text { Serie 1 } \\
\text { EODV = 4.5 V }\end{array}$ & Average & 6,47 & 20,5 & $\mathbf{1 8 6}$ \\
\hline
\end{tabular}

Table 6: Serie 2 cell characterization at $\mathrm{D} / 2$ for $\mathrm{EOCV}=4.4 \mathrm{~V}$ $\& 4.5 \mathrm{~V}$

As the cell polarization is more important at high current rate, the gain in capacity and energy is more important at $\mathrm{D} / 2$ than at $\mathrm{D} / 10$. For this last rate, the gain is negligible.

At $\mathrm{D} / 2$, the obtained specific energy is close to what was expected by design (186 Wh/kg vs. 190 $\mathrm{Wh} / \mathrm{kg}$ ).

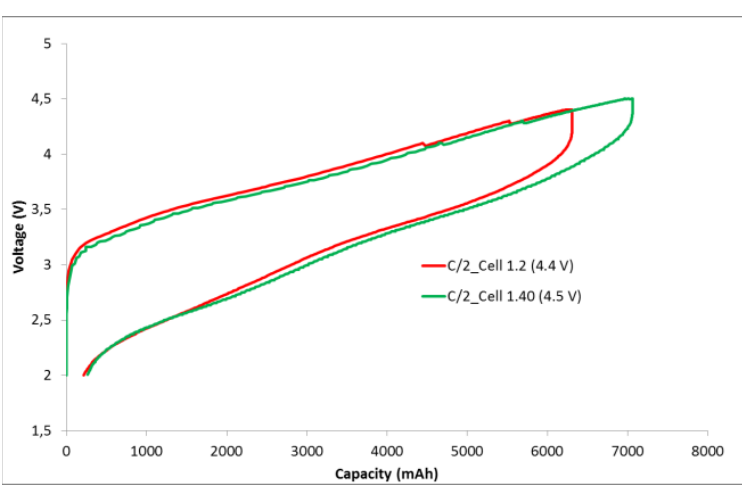

Figure 8: Voltage profiles of cells respectively charged at $4.4 \mathrm{~V}$ $\& 4.5 \mathrm{~V}$

At $\mathrm{D} / 2$, voltage profiles of two cells from Serie 1 respectively charged at $4.4 \mathrm{~V}$ and $4.5 \mathrm{~V}$ were compared. The cells present the same irreversible capacity after the charge. This implies that the charge procedure up to $4.5 \mathrm{~V}$ (current rate at $\mathrm{C} / 50$ ) has not significantly degraded the cell.

\subsubsection{Rate capability characterization}

For Serie 1, characterizations were performed for various current rates: $\mathrm{C} / 10, \mathrm{C} / 3, \mathrm{C} / 2, \mathrm{C} / 1.3, \mathrm{C}$ and 1.37C. Not enough cells were available for this kind of characterization on Serie 2.

Characterization at $\mathrm{C}$ and $1.37 \mathrm{C}$ were not able to be done due to the high self-heating of the cell and reached temperatures higher than the safety limit $\left(+45^{\circ} \mathrm{C}\right)$.

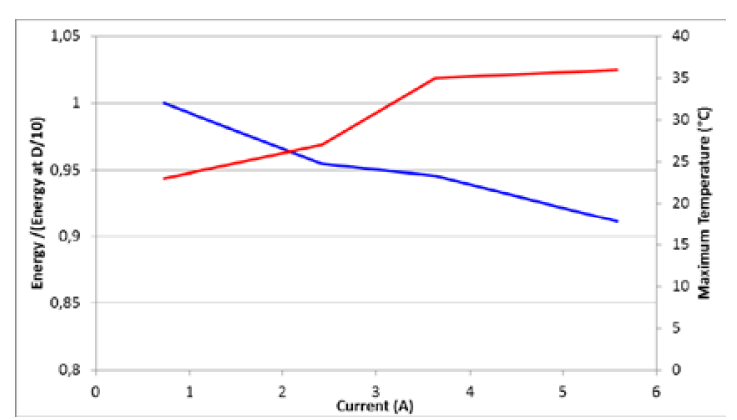

Figure 9: Serie 1 cell rate capability and maximum temperature

The energy drop is limited when the discharge current increase. The important temperature increase of the cell should have favorised the high current rate behavior.

\subsubsection{Characterization at various temperatures}

Cells were characterized at: $-10^{\circ} \mathrm{C},+20^{\circ} \mathrm{C}$ and $+50^{\circ} \mathrm{C}$ at $\mathrm{D} / 2$ with $\mathrm{EOCV}=4.4 \mathrm{~V}$.

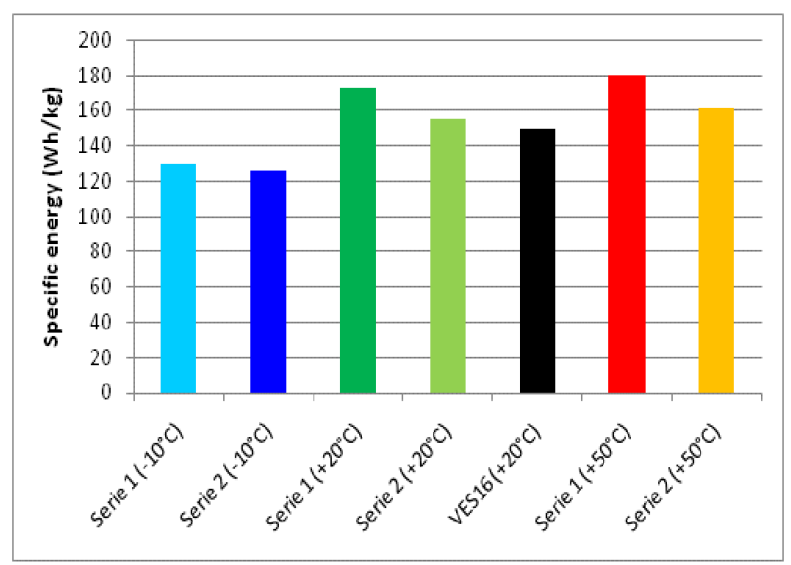

Figure 10: Prototype cell characterization results at various temperatures

For the characterization at $-10^{\circ} \mathrm{C}$, the cells still present good specific energies. Cells from Serie 2 present a lower energy drop (-18\% for Serie $2 \&$ $25 \%$ for Serie 1 ).

At $+50^{\circ} \mathrm{C}$, the cells did not gain significant energies $(\sim 4-5 \%)$ due to an increase of the cell irreversible capacity and internal resistance. 


\subsubsection{Self-discharge at $3.5 \mathrm{~V}$}

The capacity losses were around $0.12 \%$ per day for both Series.

\begin{tabular}{|c|c|c|}
\hline Cell & \multicolumn{2}{|c|}{ Self Discharge } \\
\hline $\mathrm{N}^{\circ}$ & $\mathrm{mV} /$ day & $\begin{array}{c}\text { \%capacity } \\
\text { loss/day }\end{array}$ \\
\hline Serie 1 & 1,5 & 0,12 \\
\hline Serie 2 & 1,4 & 0,12 \\
\hline
\end{tabular}

Table 7: Serie $1 \&$ Serie 2 self-discharge results

The cells are far lower the TRP requirements of 5\% capacity loss/day.

\subsubsection{Prototype cells cycling performances}

Cells were tested in GEO $(80 \%$ DoD, Discharge at $\mathrm{D} / 2$ ) (Figure 10) and LEO (20\% DoD, Discharge at $\mathrm{D} / 2$ ) (Figure 11) cycling conditions.

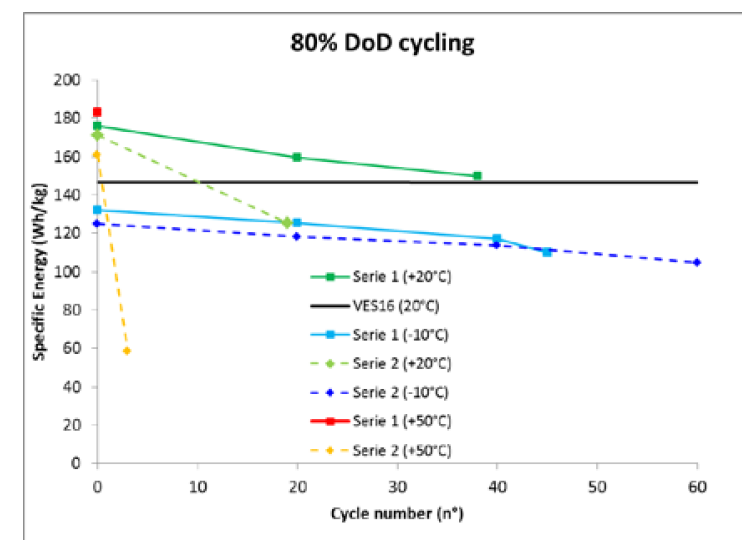

Figure 11: Prototype cell GEO cycling tests results

At $+20^{\circ} \mathrm{C}$ and $-10^{\circ} \mathrm{C}$, the constant cell fading is probably due to the instability of the negative electrode of both series. This is mostly due to the high volume changes of the electrode during cycling.

At $+50^{\circ} \mathrm{C}$, cells from Serie 1 present sudden death before the $1^{\text {st }}$ check-up and cells from Serie 2 only performed 3 cycles. These poor results could be due to internal mechanical stresses at electrodes level in the cells at such temperature.

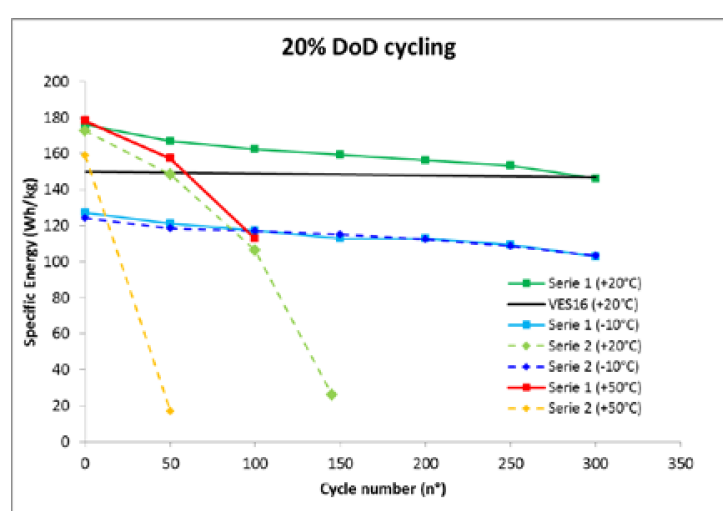

Figure 12: Prototype cell LEO cycling tests results

At $+20^{\circ} \mathrm{C}$ and $-10^{\circ} \mathrm{C}$, cells from Serie 1 were able to cycle 300 cycles with energy losses below $20 \%$. The low DoD cycling has limited the volume change of the negative electrode and improve its stability during cycling.

At $-10^{\circ} \mathrm{C}$, cells from Serie 2 were able to cycle 300 cycles with energy losses below $20 \%$.

At $+20^{\circ} \mathrm{C}$, before the $1^{\text {st }}$ check-up ( 20 cycles), Serie 2 electrode presents a similar fading as Serie 1 confirming the better stability of Si based electrode at low DoD cycling. Then a higher degradation rate was observed. Post mortem analyses confirm that the cells encountered a mechanical issue due to high stress on the electrode (high volume changes). At $+50^{\circ} \mathrm{C}$, cells from Serie 2 only performed 50 cycles. Cells from Serie 1 present sudden death after 100 cycles. Again, these poor results could be due to internal mechanical stresses at electrodes level in the cells at such temperature.

\section{CONCLUSION}

\subsection{Main achievements}

HENMC and Si carbon alloys were selected for evaluation and implementation in Format prototype cells.

Preliminary results on coin cell permit to design full prototype cells.

Prototypes cells were successfully assembled and formed. However they present lower specific energy then design prediction. This is mainly due to the high polarization of positive and negative electrode.

The cycling stability in LEO cycling conditions at $20^{\circ} \mathrm{C}$ and $-10^{\circ} \mathrm{C}$ are conformed to the objectives. At $+50^{\circ} \mathrm{C}$, the cells seem to encountered mechanical issue leading to their sudden death.

In GEO cycling conditions, the high volume change of the electrodes may induce a high cell degradation which did not permit to reach the objectives.

\subsection{Way forward}

Work can be done to Improve (-) and (+) electrode polarization at high current by working on material coating and/or electrode formulation. An additional test at higher end of charge voltage has shown that the specific energy design prediction can be reached if the electrode polarization is lower.

Prototype D cell design was not adapted to electrode volume change during cycling. Mechanical issues were observed on cells from Serie 2 and probably on cells from Serie 1 cycled at $+50^{\circ} \mathrm{C}$. The solutions could be:

- To develop prototype cell with a mechanical design generating lower stress on the electrode: Pouch cell with stack electrodes can be a solution.

- To introduce less $\mathrm{SiC}$ in negative electrode in order to limit volume change during cycling.

Using another cell design can be the opportunity to gain as well specific energy. 